\title{
Impacts of Pig Manure-Based Liquid Fertilizer Agricultural Application on the Water Quality of Agricultural Catchment
}

\author{
Min-Kyeong Kim, Soon-Ik Kwon*, Hyen-Cheng Chun, Goo-Bok Jung, Kee-Kyung Kang \\ Department of Agricultural Environment, National Academy of Agricultural Science, Rural Development Administration, Suwon, \\ South Korea. \\ Email: "kimmk72@korea.kr
}

Received October $9^{\text {th }}, 2012$; revised November $10^{\text {th }}, 2012$; accepted December $11^{\text {th }}, 2012$

\begin{abstract}
This study was conducted to understand the effect of the livestock liquid fertilizer treatment at field-scale up to catchment-scale on the water quality properties. Cultivated paddy rice and upland plots located in Gyeonggi province, Korea were treated with two different liquid fertilizers, SP (Liquid fertilizer with storage process) and SCB (Liquid fertilizer with slurry composting and bio-filtration process). Plots with no fertilizer (control A) and chemical fertilizer (control B) were also prepared for comparison. Water quantity and quality were monitored at the catchment outlet for assessing the effect on water quality of stream water. As a result, the losses of $\mathrm{N}$ and $\mathrm{P}$ and the values of EC (Electronic Conductivity) in the surface drainage water from paddy rice plots treated with SP and SCB were higher than those from the control plots (A and B). In addition, the losses of $\mathrm{N}$ and $\mathrm{P}$ by the runoff water from upland plots with SP and SCB treatment were higher than those from control plots (A and B). The nutrient outflow from paddy rice fields and uplands with application of liquid pig manure was higher than those from the control plots (A and B). Particularly, the outflow from uplands may directly affect the water quality in neighboring streams. This caused the major eutrophication problem in stream water. In conclusion, it is necessary to establish the proper management practices to prevent the nutrient losses from agricultural fields and the pollutants against water environments.
\end{abstract}

Keywords: Liquid Fertilizer; Livestock Manure; Paddy Field; Upland; Water Quality

\section{Introduction}

Traditionally, livestock manure-based composts and liquid fertilizers have been used for agricultural purposes, since they contain a wide range of nutrients and ameliorate soil properties. In 2009, 43.7 million tons of livestock manures were generated in Korea and $85.6 \%$ of the manures were used for composts and liquid fertilizer productions [1]. This has resulted in intensive farming practices where large numbers of animals are raised in relatively small areas. This farming condition produces large amount of wastes (e.g. farmyard manure, slurry, dirty water, silage effluents and poultry litter) and local disposals of the wastes become more difficult by the limited area for the disposals.

Liquid livestock manure is a valuable source of nutrients and organic matter for crop production and can be applied with a variety of methods including spray irrigation, land surface spreading and shallow subsurface injection. Because of relatively low nutrient concentration,

\footnotetext{
${ }^{*}$ Corresponding author.
}

liquid livestock manure need to be applied in large volumes. But the recommended application rate is not to exceed the soil infiltration rate, nor to exceed the amount of field water holding capacity [2,3]. Previous study reported that even if recommended guidelines are followed, liquid manure from agricultural drains can be discharged out through the farmland via macropore flow within soil [4].

Application of liquid livestock manures to soils with surface or subsurface drainage has been linked to contamination of the effluent with nutrients $[5,6]$, particulate organic matters [7,8], estrogens [9], bacteria [10-12] and antibiotics [13].

Based on previous studies, there has been no proof that liquid livestock manures can negatively affect water quality. For instance, Randall et al. [14] noted that there was no difference in nitrogen, phosphorus, or fecal indicator bacteria losses in drainage effluent between plots with liquid dairy manure and plots with mineral fertilizer.

The fact that nutrients from liquid livestock manure can be safely recycled in soil, but they can be also dis- 
charged into surface or subsurface drainage water. This suggests that there should be a complex system to manage the discharge of liquid livestock manure into soil. Many factors play a role in determining the manure management; soil texture, available water holding capacity, tillage history, the type and quantity of manure applied, application method and timeliness of rainfall after application.

As the areas of livestock manure application increase over time in Korea, interests of livestock manure application have increased for sustainable agriculture. The manure applications to agricultural lands have the merit of nutrient supply for crops, but they also have a demerit of polluting agricultural environments such as deteriorating water quality near the agricultural areas. In spite of ever-increasing usage of livestock manure to the agricultural areas, its environmental impact on neighboring streams has not been well known. Therefore, this study was conducted to understand the effects of the livestock liquid fertilizer treatment on water quality at field-scale and catchment-scale, when the fertilizers were applied to paddy fields and upland fields.

\section{Materials and Methods}

\subsection{Study Area Description}

This study was conducted in a small agricultural catchment (132 ha) which is located in Yoeju, Gyeonggi province of Korea $\left(37^{\circ} 16^{\prime} 32.22^{\prime \prime} \mathrm{N}, 127^{\circ} 35^{\prime} 21.32^{\prime \prime} \mathrm{E}\right)$ (Figure 1). The catchment consists of $17 \%$ paddy rice field and $20.5 \%$ upland. The experimental plots in paddy rice field and cultivated upland were located in the catchment. Soils in a paddy rice field and upland were all sandy loam, and soil pH were 5.8 and 6.4, respectively (Table 1). In addition, the organic matter contents were 19.6 and $26.4 \mathrm{~g} \cdot \mathrm{kg}^{-1}$ for a paddy rice field and upland, respectively. The available phosphate content from upland was 967 $\mathrm{mg} \cdot \mathrm{kg}^{-1}$ which was much higher than onesfrom paddy rice field soil.

Two different pig manure-based liquid fertilizers were applied in this study, which were bio-filtration process
(SCB) and storage process (SP) (Table 2). Nitrogen contents in SCB and SP liquid fertilizers were 0.26 and $0.40 \%$, respectively. The content of potassium in SCB liquid fertilizers was especially greater than the other. It was caused by the content of the soluble potassium in the liquid type fertilizers. The content of the soluble potassium in urine was greater than ones in feces. Therefore, it was easily drained to the outside of filtering system without being filtered out during the process of SCB.

They were applied to the total of 16 plots ( 4 for paddy rice field and 12 for upland) in the studied catchment, and the size of each plot was $20 \times 36 \mathrm{~m}$ for a paddy rice field and $2.7 \times 10 \mathrm{~m}$ for upland. The amount of $\mathrm{N}$ requirement was pre-calculated for the crop cultivation. For comparison, the experimental plots also included no fertilization plots (control A) and chemical fertilization plots (control B). Paddy rice (Oryza sativa L.) was transplanted into each experimental plot at the space $15 \times 30$ $\mathrm{cm}$ and grown for five months. Corn seeds (Zea mays L.) were sowed in each experimental plot at the space of 20 $\times 60 \mathrm{~cm}$ and grown for three months.

In order to assess the effect of livestock manure appli-

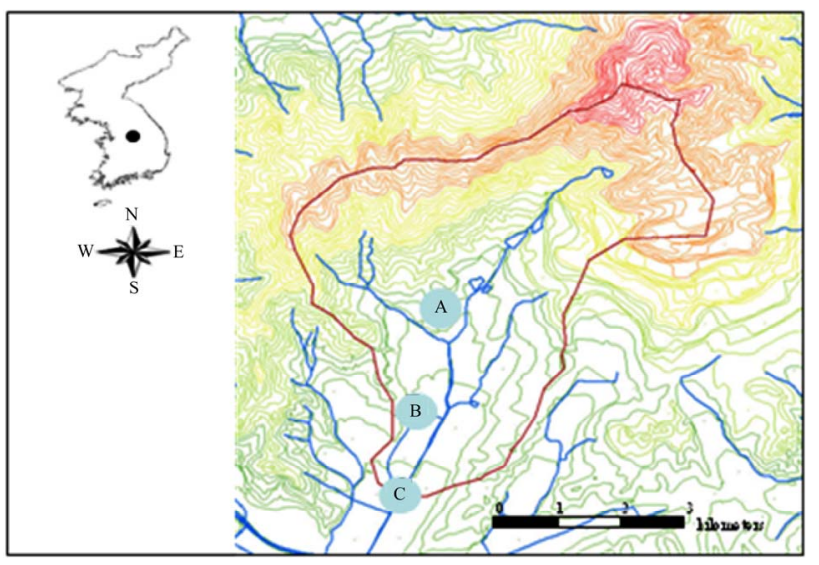

Figure 1. A map showing the location of the sampling catchment (outlined by red line) in Yoeju, Gyeonggi Province, Korea (A; Upland, B; Paddy rice field, C; Outlet of the catchment).

Table 1. Chemical properties from paddy rice field and upland before the experiment.

\begin{tabular}{|c|c|c|c|c|c|c|c|c|}
\hline & $\mathrm{pH}(1: 5)$ & $\mathrm{EC}\left(\mathrm{dS} \cdot \mathrm{m}^{-1}\right)$ & $\mathrm{OM}\left(\mathrm{g} \cdot \mathrm{kg}^{-1}\right)$ & $\mathrm{P}_{2} \mathrm{O}_{5}\left(\mathrm{mg} \cdot \mathrm{kg}^{-1}\right)$ & Ex. $\mathrm{K}\left(\mathrm{cmol} \cdot \mathrm{kg}^{-1}\right)$ & Ex. $\mathrm{Ca}\left(\mathrm{cmol} \cdot \mathrm{kg}^{-1}\right)$ & Ex. $\mathrm{Mg}\left(\mathrm{cmol} \cdot \mathrm{kg}^{-1}\right)$ & Ex. $\mathrm{Na}\left(\mathrm{cmol} \cdot \mathrm{kg}^{-1}\right)$ \\
\hline Paddy field & 5.8 & 0.36 & 19.6 & 167 & 0.23 & 2.87 & 0.80 & 1.09 \\
\hline Upland & 6.4 & 0.50 & 26.4 & 967 & 1.09 & 6.31 & 2.06 & 0.10 \\
\hline
\end{tabular}

Table 2. Chemical properties and heavy metals from liquid fertilizers that were applied to paddy rice field and upland.

\begin{tabular}{ccccccccc}
\hline & $\mathrm{pH}$ & $\mathrm{EC}\left(\mathrm{dS} \cdot \mathrm{m}^{-1}\right)$ & $\mathrm{T}-\mathrm{N}(\%)$ & $\mathrm{P}_{2} \mathrm{O}_{5}(\%)$ & $\mathrm{K}_{2} \mathrm{O}(\%)$ & $\mathrm{CaO}(\%)$ & $\mathrm{MgO}(\%)$ & $\mathrm{Na}_{2} \mathrm{O}(\%)$ \\
\hline $\mathrm{SCB}$ & 8.8 & 19.4 & 0.26 & 0.05 & 0.22 & 0.034 & 0.017 & 0.058 \\
$\mathrm{SP}$ & 8.3 & 19.6 & 0.40 & 0.33 & 0.20 & 0.211 & 0.147 & 0.051 \\
\hline
\end{tabular}

*SCB: Liquid fertilizer with slurry composting and bio-filtration process; SP: Liquid fertilizer with storage process. 
cation on land at catchment-scale, water quantity and quality were monitored at the catchment outlet. A set of equipments was installed to measure water level and velocity (Starflow, Ultrasonic Dopper Instrument, Unidata Co., Australia) at the monitoring site. Water quality was monitored in stream nearby the investigated paddy rice field and cultivated upland during the cultivation period from May to October in 2009.

\subsection{Sample Collection and Analyses}

Water samples were collected from paddy rice field and upland as well as stream water to monitor the changes of water quality properties during the cultivation period. All samples were refrigerated at 0 to $4^{\circ} \mathrm{C}$ soon after collected and stored in the refrigerator until the analyses. Water samples were transported to the laboratory in RDA (Rural Development Administration, Suwon, Korea) and were shaken to obtain homogeneous aliquots for the analyses.

Electrical conductivity (EC) was measured in the field with portable meters (Model 145A, Orion Co., USA). The samples from the drainage water/runoff and stream water were analyzed for suspended solids (SS) and chemical oxygen demands (COD), nitrogen and phosphorous concentrations. SS and COD were analyzed by the Standard Methods [15] and by the dichromate reflux method [16]. The $\mathrm{NO}_{3}-\mathrm{N}$ and $\mathrm{NH}_{4}-\mathrm{N}$ were analyzed using ion chromatography (DX-100, Ion Chromatograph, Dionex Co., USA) and using the indophenols-blue method [17] through $0.45 \mu \mathrm{m}$ nylon membrane filter, respectively. Total N (T-N) was analyzed by the standard methods according to the Federal Water Pollutant Clean Act (FWPCA) manual [18] and total P (T-P) was measured by the isobutanol extraction method described by Golterman and Glymo [19].

\section{Results and Discussion}

\subsection{Nutrient Loss in Surface Runoff at Paddy Rice Field and Upland}

The combined use of livestock manure and mineral fertilizer results in considerable nutrient enrichment in soil surface [2] and overland flow from such areas during or after a rainfall event. The flow contains relatively high levels of nutrients (e.g. N, P, K), organic matter and suspended particles [20,21].

Table 3 shows the observed concentrations of $\mathrm{N}$ and $\mathrm{P}$ in surface drainage waters from paddy rice field during the cultivation period. The SS concentration in water samples were ranged from 0.01 to $0.07 \mathrm{mg} \cdot \mathrm{L}^{-1}$ for all treatments. The concentrations of T-N and T-P in drainage waters were $1.85-3.45$ and $0.18-0.44 \mathrm{mg} \cdot \mathrm{L}^{-1}$, respectively. The concentrations of $\mathrm{N}$ and $\mathrm{P}$ and the $\mathrm{EC}$ values from SP and SCB treated plots were much higher than the ones from control A (no fertilization) and control B (chemical fertilization) (Table 3). Therefore, there is a need to manage drainage water from SP and SCB treated areas.

Manure is generally composed of $\mathrm{NH}_{4}-\mathrm{N}$ and organic$\mathrm{N}$. Thses components are often mixed with equal ratios. $\mathrm{NH}_{4}-\mathrm{N}$ is more flavorable to plants than organic- $\mathrm{N}$, because $\mathrm{NH}_{4}-\mathrm{N}$ is readily available to plant. In the meantime, organic- $\mathrm{N}$ needs to be mineralized to become available for plants. $\mathrm{NH}_{4}-\mathrm{N}$ originated from manure was found to be biologically oxidised into $\mathrm{NO}_{3}-\mathrm{N}$ before it was converted into organic-N. This causes $\mathrm{N}$ losses in Manure [22]. Therefore, the effect of nitrate loss by manure application needs to be largely determined by plant uptake and the factors that control the processess of $\mathrm{N}$ mineralisation and nitrification. Phosphorus transport in surface runoff occurs both in soluble and particulate forms. Phosphorus is generally transported in particulate form $[8,23]$. The transport is influenced by several factors, including land use, management practices, soil type, time and rate of fertilizer and manure application.

Table 4 shows the observed concentrations of $\mathrm{N}$ and $\mathrm{P}$ in runoff waters from upland during the cultivation period. The SS concentrations in water samples were ranged from 1.0 to $1.7 \mathrm{mg} \cdot \mathrm{L}^{-1}$ for all treatments. The T-N and T-P concentrations in runoff water samples were 6.07 - 8.45 and $1.39-3.02 \mathrm{mg} \cdot \mathrm{L}^{-1}$ during the rainfall events. Losses of N and P by the runoff waters from SP and SCB treated plots were higher than the ones from the control plots (A and B). Particularly, the loss of nitrate-nitrogen was greater than the loss of ammonium-nitrogen, and this can be explained by the nitrification process in manure as

Table 3. Water quality properties in the drainage waters from paddy rice fields.

\begin{tabular}{cccccccc}
\hline Treatment & $\mathrm{SS}\left(\mathrm{g} \cdot \mathrm{L}^{-1}\right)$ & $\mathrm{EC}\left(\mathrm{dS} \cdot \mathrm{m}^{-1}\right)$ & $\mathrm{NH}_{4}-\mathrm{N}\left(\mathrm{mg} \cdot \mathrm{L}^{-1}\right)$ & $\mathrm{NO}_{3}-\mathrm{N}\left(\mathrm{mg} \cdot \mathrm{L}^{-1}\right)$ & $\mathrm{T}-\mathrm{N}\left(\mathrm{mg} \cdot \mathrm{L}^{-1}\right)$ & $\mathrm{PO}-\mathrm{P}\left(\mathrm{mg} \cdot \mathrm{L}^{-1}\right)$ & $\mathrm{T}-\mathrm{P}\left(\mathrm{mg} \cdot \mathrm{L}^{-1}\right)$ \\
\hline Control & $0.01 \pm 0.01$ & $0.07 \pm 0.09$ & $0.07 \pm 0.13$ & $1.22 \pm 1.01$ & $1.85 \pm 0.95$ & $0.01 \pm 0.02$ & $0.18 \pm 0.07$ \\
$\mathrm{CF}$ & $0.01 \pm 0.02$ & $0.09 \pm 0.11$ & $0.09 \pm 0.12$ & $2.14 \pm 1.75$ & $2.28 \pm 0.64$ & $0.03 \pm 0.02$ & $0.39 \pm 0.03$ \\
$\mathrm{SP}$ & $0.07 \pm 0.05$ & $0.16 \pm 0.16$ & $0.17 \pm 0.13$ & $3.45 \pm 2.20$ & $3.45 \pm 2.20$ & $0.05 \pm 0.03$ & $0.44 \pm 0.20$ \\
$\mathrm{SCB}$ & $0.03 \pm 0.04$ & $0.08 \pm 0.12$ & $0.16 \pm 0.15$ & $1.64 \pm 1.10$ & $2.63 \pm 2.06$ & $0.01 \pm 0.01$ & $0.21 \pm 0.18$ \\
\hline
\end{tabular}

${ }^{*} \mathrm{CF}$ : Chemical fertilization; SP: Liquid fertilizer with storage process; SCB: Liquid fertilizer with slurry composting and bio-filtration process; ${ }^{* *}$ Data are expressed as mean $\pm \mathrm{SD}(\mathrm{n}=8)$. 
Table 4. Water quality properties in run-off water with application of liquid pig manure at the study upland.

\begin{tabular}{cccccccc}
\hline Treatment & $\mathrm{TSS}\left(\mathrm{g} \cdot \mathrm{L}^{-1}\right)$ & $\mathrm{EC}\left(\mathrm{dS} \cdot \mathrm{m}^{-1}\right)$ & $\mathrm{NH}_{4}-\mathrm{N}\left(\mathrm{mg} \cdot \mathrm{L}^{-1}\right)$ & $\mathrm{NO}_{3}-\mathrm{N}\left(\mathrm{mg} \cdot \mathrm{L}^{-1}\right)$ & $\mathrm{T}-\mathrm{N}\left(\mathrm{mg} \cdot \mathrm{L}^{-1}\right)$ & $\mathrm{PO}_{4}-\mathrm{P}\left(\mathrm{mg} \cdot \mathrm{L}^{-1}\right)$ & $\mathrm{T}-\mathrm{P}\left(\mathrm{mg} \cdot \mathrm{L}^{-1}\right)$ \\
\hline Control & $1.7 \pm 2.0$ & $0.03 \pm 0.02$ & $0.41 \pm 0.02$ & $1.45 \pm 0.52$ & $6.07 \pm 2.23$ & $0.56 \pm 0.22$ & $1.39 \pm 1.36$ \\
$\mathrm{CF}$ & $1.0 \pm 0.7$ & $0.04 \pm 0.03$ & $0.47 \pm 0.16$ & $1.66 \pm 1.11$ & $6.15 \pm 0.89$ & $0.61 \pm 0.26$ & $2.58 \pm 1.25$ \\
$\mathrm{SP}$ & $1.6 \pm 1.0$ & $0.10 \pm 0.06$ & $0.43 \pm 0.29$ & $2.47 \pm 2.21$ & $8.45 \pm 4.16$ & $1.15 \pm 0.50$ & $3.02 \pm 3.06$ \\
$\mathrm{SCB}$ & $1.0 \pm 0.9$ & $0.04 \pm 0.02$ & $0.47 \pm 0.32$ & $1.84 \pm 0.68$ & $8.09 \pm 3.80$ & $0.68 \pm 0.32$ & $2.82 \pm 0.51$ \\
\hline
\end{tabular}

${ }^{*} \mathrm{CF}$ : Chemical fertilization; SP: Liquid fertilizer with storage process; SCB: Liquid fertilizer with slurry composting and bio-filtration process; ${ }^{* *}$ Data are expressed as mean $\pm \operatorname{SD}(n=7)$.

described above.

Similar to $\mathrm{N}$ loss in Manure, several factors affect phosphorous loss by surface runoff; land use and management practices, soil type, time and rate of fertilizer and manure application. Consequently, nutrient leach from agricultural land flows into surface water and this causes acceleration of eutrophication in the surface water. In the end, the influx of excess nutrients contributes to the degradation of surface waters $[20,23]$. This nutrient leach from agricultural land can be an important factor to not only soil or water, but to the whole environments.

\subsection{Nutrient Loss in Surface Water through Agricultural Land}

Figure 2 shows the changes of nutrient concentrations in stream water near the experimental sites of a paddy rice field and upland during the cultivation period. A lot of nutrient inputs for crop cultivation were applied to agricultural lands, particularly from May to June (the cultivation period). These nutrient inputs caused higher concentration of nutrients to the drainage waters during the cultivation period. Therefore, the concentrations of COD, T-N and T-P during the early cultivation period, May and June, were higher than the ones in July through August when it was the rainy season.

Rainfall events characteristically govern the nutrient of streams draining from livestock areas. Generally, when there is no rainfall, the level of nutrients including BOD remains within normal range in surface waters unless farm effluents are discharged directly into streams. This effluent may have even greater nutrient concentration if there has been no rainfall event [24]. In addition, the impact intensity of land use on water quality was as great as the amount of surplus nutrient in cropland from the respective drainage watershed [3]. Therefore, a proper management of cropland is very important in protecting the quality of stream/river water, e.g. managing paddy rice field and upland proportions in drainage watersheds and of surplus nutrient.

Table 5 shows the monthly distribution of discharge water and nutrient loads into stream water during the cultivation period. The total amount of precipitation in

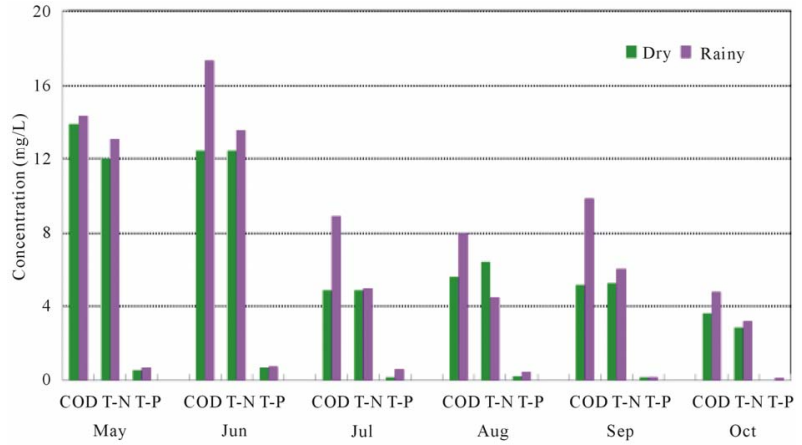

Figure 2. Changes of the COD, T-N and T-P concentrations in stream waters nearby paddy rice fields and uplands at rainy and non-rainy days during the crop cultivation period.

Table 5. Monthly discharge water and nutrient loads in streams located nearby paddy fields and uplands during the crop cultivation period.

\begin{tabular}{cccccc}
\hline \multirow{2}{*}{ Month } & $\begin{array}{c}\text { Rainfall } \\
(\mathrm{mm})\end{array}$ & $\begin{array}{c}\text { Discharge } \\
(\mathrm{mm})\end{array}$ & \multicolumn{3}{c}{ Loads $\left(\mathrm{kg} \cdot \mathrm{month}^{-1}\right)$} \\
\cline { 4 - 6 } & & & COD & T-N & T-P \\
\hline May & 118.9 & 11,203 & 156 & 141 & 7.3 \\
Jun. & 105.0 & 4437 & 55 & 58 & 3.3 \\
Jul. & 644.9 & 66,056 & 324 & 328 & 26.4 \\
Aug. & 195.7 & 12,101 & 68 & 67 & 4.5 \\
Sept. & 45.5 & 10,016 & 52 & 57 & 2.0 \\
Oct. & 53.0 & 2065 & 8 & 6 & 0.2 \\
Total & 1163.0 & 105,878 & 663 & 657 & 43.7 \\
\hline
\end{tabular}

2009 was $1163 \mathrm{~mm}$ and the monthly precipitation was constantly high in July and August. The highest monthly precipitation was occurred in July, 2009 and the amount of precipitation was almost $55.5 \%$ of the annual precipitation in Korea. Discharge water, chemical and nutrient loads were recorded the highest in July, the highest precipitation month. It shows that precipitation is the most significant factor on water, chemical and nutrient loads which influence the water quality in streams.

Generally, small scale sites have a clear positive rela- 
tionship between the loads of leached nutrient and rainfall [25]. Previous study reported that the changes in the nutrient concentrations of the drainage water over rainfall events indicated the transport of the particulate materials and of the nutrients such as nitrogen and phosphorus were mainly influenced by direct runoff and base flow, respectively [6].

Therefore, it is important that the loss of nutrients in surface runoff should be minimized for the sustainable agriculture and water quality. This can be done by adapting the best management practices considering the climate and crop cultivation condition. Because of this, riparian croplands have been major targets to manage nutrient losses in surface runoff. Since the dissolved nitrogen ratio was found to be high in base flow, managing spring water can be a solution to effectively reduce dissolved nitrogen [6]. Therefore, in case of upland cultivation, buffer strips and wetlands are effective managements to reduce both particulate and dissolved materials in runoff. In case of rice cultivation in paddy fields, it is important to manage irrigation and drainage waters at the early cultivation period in paddy rice fields to increase nutrient use efficiency and prevent nutrient losses.

\section{Conclusions}

Livestock manures and chemical fertilizers are essential for crop production, but sometimes their excessive uses cause water pollution.

Losses of $\mathrm{N}$ and $\mathrm{P}$ in the drainage and runoff water samples from paddy rice field and upland treated with SP and SCB were higher than the ones from paddy rice field and upland treated with no fertilizer and chemical fertilizer. Especially, the outflow from agricultural field could directly affect the water quality of stream. The nutrient concentrations in stream water near the experimental sites, a paddy rice field and upland in May and June (dry and early cultivation period) were higher than the ones in July and August (rainy season). This was explained by a lot of nutrient inputs which were applied to the agricultural land for crop cultivation. However, nutrient discharges were changed dramatically during rainy season, and it also caused the eutrophication problem in stream. Overall, it is important to establish the proper management practices to prevent the loss of nutrient from agricultural fields and pollutants against water qualities.

Improved management is a key issue in greatly reducing the potential of liquid manure reaching to surface water. While climate and some environmental conditions cannot be controlled, farmers can manage and control leach of nutrients by proper applications of liquid manure and proper water management. In order to encourage the utilization of liquid fertilizer and ensure protection of the water quality, practices are recommended that control a drainage water gate in paddy rice field at the early culti- vation period. In addition, it is recommended that liquid manure should be applied in a way to minimize impact to water resources in upland.

\section{Acknowledgements}

This study was carried out with the support of "Research Program for Agricultural Science \& Technology Development (Project No. 008507)", National Academy of Agricultural Science, Rural Development Administration, South Korea.

\section{REFERENCES}

[1] Ministry of Environment, "Environmental Statistics Yearbook," No. 24, Ministry of Environment, Gwacheon-si, Report \#11-1480000-000081-10, 2011.

[2] N. M. Pieterse, W. Blueten and S. E. Jorgensen, "Contribution of Point Sources and Diffuse Sources to Nitrogen and Phosphorus Loads in Lowland River Tributaries," Journal of Hydrology, Vol. 27, No. 1-4, 2003, pp. 213225. doi:10.1016/S0022-1694(02)00350-5

[3] K. P. Woli, T. Nagumo, K. Kuramochi and R. Hatano, "Evaluating River Water Quality through Land Use Analysis and N Budget Approaches in Livestock Farming Areas," Science of the Total Environment, Vol. 329, No. 1-3, 2004, pp. 61-74. doi:10.1016/j.scitotenv.2004.03.006

[4] L. D. Geohring, O. V. McHugh, M. T. Walter, T. S. Steenhuis, M. S. Akhtar and M. F. Walter, "Phosphorus Transport into Subsurface Drains by Macropores after Manure Applications: Implications for Best Manure Management Practices," Soil Scicence, Vol. 166, No. 12, 2001, pp. 896-909. doi:10.1097/00010694-200112000-00004

[5] H. Steinfeld, P. Gerber, T. Wassenaar, V. Castel, M. Rosales and C. de Haan, "Livestock's Long Shadow; Environmental Issues and Options," FAO, Rome, 2006.

[6] T. Kato, H. Kuroda and H. Nakasone, "Runoff Characteristics Of Nutrients from an Agricultural Watershed with Intensive Livestock Production," Journal of Hydrology, Vol. 368, No. 1-4, 2009, pp. 79-87. doi:10.1016/j.jhydrol.2009.01.028

[7] D. K. Borah, M. Bera and S. Shaw, "Water, Sediment, Nutrient, and Pesticide Measurements on an Agricultural Watershed in Illinois during Storm Events," Transactions of the American Society of Agricultural Engineers, Vol. 46, 2003, pp. 657-674.

[8] M. I. Stutter, S. J. Langana and R. J. Cooper, "Spatial Contributions of Diffuse Inputs and Within-Channel Processes to the form of Stream Water Phosphorus over Storm Events," Journal of Hydrology, Vol. 350, No. 3-4, 2008, pp. 203-214. doi:10.1016/j.jhydrol.2007.10.045

[9] B. K. Burnison, A. Hartmann, A. Lister, M. R. Servos, T. Ternes and G. G. Van Der Kraak, "A Toxicity Identification Evaluation Approach to Studying Estrogenic Substances in Hog Manure and Agricultural Runoff," Environmental Toxicology and Chemistry, Vol. 22, No. 10, 2003, pp. 2243-2250. doi:10.1897/02-437 
[10] J. R. Bicudo and S. M. Goyal, "Pathogens and Manure Management Systems: A Review," Environmental Technology, Vol. 24, No. 1, 2003, pp. 115-130. doi:10.1080/09593330309385542

[11] M. J. Cook and J. L. Baker, "Bacteria and Nutrient Transport to Tile Lines Shortly after Application of Large Volumes of Liquid Swine Manure," Transactions of the American Society of Agricultural Engineers, Vol. 44, No. 3, 2001, pp. 495-503.

[12] R. C. Jamieson, R. J. Gordon, K. E. Sharples, G. W. Stratton and A. Madani, "Movement and Persistence of Fecal Bacteria in Agricultural Soils and Subsurface Drainage Water: A Review," Canadian Biosystems Engineering, Vol. 44, 2002, pp. 1.1-1.9.

[13] P. Kay, P. A. Blackwell and A. B. A. Boxall, "Fate of Veterinary Antibiotics in a Macroporous Tile Drained Clay Soil," Environmental Toxicology and Chemistry, Vol. 23, No. 5, 2004, pp. 1136-1144. doi:10.1897/03-374

[14] G. W. Randall, T. K. Iragavarapu and M. A. Schmitt, "Nutrient Losses in Subsurface Drainage Water from Dairy Manure and Urea Applied for Corn," Journal of Environmental Quality, Vol. 29, No. 4, 2000, pp. 12441252. doi:10.2134/jeq2000.00472425002900040031x

[15] American Public Health Association, American Water Works Association and Water Pollution Control Federation, "Standard Methods for the Examination of Water and Wastewater," 20th Edition, AOAC International, Washington DC, 1998.

[16] S. R. Olsen and L. E. Sommers, "Phosphorus," In: A. L. Page, et al., Eds., Methods of Soil Analysis, Part 2, 2nd Edition, ASA and SSSA, Madison, 1982, pp. 403-430.

[17] J. M. Bremmner and C. S. Mulvancy, "Nitrogen-Total," In: A. I. Page, et al., Eds., Methods of Soil Analysis, Part 2, 2nd Edition, ASA and SSSA, Madison, 1982, pp. 595624.
[18] United States Department of the Interior, "FWPCA Methods for Chemical Analysis of Water Wastes," National Environmental Research Center, Ohio, 1971.

[19] H. L. Golterman and R. S. Glymo, "Methods for Chemical Analysis of Fresh Waters," Blackwell Science Publisher, Oxford, 1969.

[20] A. N. Sharpley, T. Daniel, T. Sims, J. Lemunyon, R. Stevens and R. Parry, "Agricultural Phosphorus and Eutrophication," 2nd Edition, US Department of Agriculture, Agricultural Research Service, Washington DC, 2003.

[21] Millennium Ecosystem Assessment, "Ecosystems and Human Well-Being: Current State and Trends," Findings of the Condition and Trends Working Group, Chapter 12, Island Press, Washington DC, 2005.

[22] P. S. Hooda, A. C. Edwards, H. A. Anderson and A. Miller, "A Review of Water Quality Concerns in Livestock Farming Areas," Science of the Total Environment, Vol. 250, No. 1-3, 2000, pp. 143-167. doi:10.1016/S0048-9697(00)00373-9

[23] M. K. Kim, S. I. Kwon, G. B. Jung, M. Y. Kim, S. B. Lee and D. B. Lee, "Phosphorus Losses from Agricultural Soils to Surface Waters in a Small Agricultural Watershed," Biosystems Engineering, Vol. 109, No. 1, 2011, pp. 10-14. doi:10.1016/j.biosystemseng.2011.01.009

[24] P. S. Hooda, M. Moynagh, I. F. Svoboda and A. Miller, "Macroinvertebrates as Bioindicators of Water Pollution in Streams Draining Dairy Farming Catchments," Journal of Chemical Ecology, Vol. 17, No. 1, 2000, pp. 17-30. doi: $10.1080 / 02757540008037658$

[25] J. J. Drewry, L. T. H. Newham and B. F. W. Croke, "Suspended Sediment, Nitrogen and Phosphorus Concentrations and Exports during Storms-Events to the Tuross Estuary, Australia," Journal of Environmental Management, Vol. 90, No. 2, 2009, pp. 879-887. doi:10.1016/j.jenvman.2008.02.004 